\title{
A KOGNITÍV IDEGTUDOMÁNY ELMÚLT 30 ÉVE
}

\section{CZIGLER ISTVÁN}

\author{
Kognitív Idegtudományi és Pszichológiai Intézet, TTK, Budapest, Magyarország \\ E-mail: czigler.istvan@ttk.hu
}

Benyújtva: 2021. február 22. - Elfogadva: 2021. március 16.

\begin{abstract}
A kognitív idegtudomány klasszikus területei közül a szerzố összefoglalja az észlelés, figyelem, tanulás és emlékezés területének hazai idegtudományi vizsgálatait, fóként az agyi elektromos müködések módszerére koncentrálva. Külön területként mutatja be az öregedéssel kapcsolatos eredményeket.
\end{abstract}

Kulcsszavak: észlelés, figyelem, memória, nyelv, öregedés, perspektívák 
Amit ma kognitív idegtudománynak hívunk, azt harminc évvel ezelôtt a pszichofiziológia egyik területének neveztük. Van azonban egy különbség. Bár a pszichofiziológia tárgyát többféleképpen határozták meg, többen úgy tekintettük, hogy a pszichofiziológia pszichológiai kérdéseket kíván megoldani fiziológiai módszerek bevonásával. A kognitív idegtudományból kimarad a vegetatív változók vizsgálatának témaköre, ${ }^{1}$ viszont bevonódott egy olyan irányzat, mely fordítva gondolkozik: közvetlenül idegrendszeri mechanizmusok alapján próbál pszichológiai jelenségeket magyarázni. Mára a két irány egyenrangúvá vált. Jelen összefoglalás (kompetencia hiányában) nem foglalkozik azokkal a kutatásokkal, melyek a pszichológiát „zárójelbe téve” közvetlenül, általában állatkísérletes eredmények alapján magyarázzák, illetve transzlációs hozzáállással foglalkoznak pszichológiai jelenségekkel. Az idegtudomány fejlődéslélektanhoz tartozó kutatásaival külön írás foglalkozik.

A „kognitív” kifejezést jelen kontextusban kétféleképpen lehet értelmezni. A szúkebb értelemben vett kognitív pszichológia irányzat, gondolkodásmód, a tágabb értelmezés pedig a megismerési folyamatokkal foglalkozó kutatásokról szól. Jelen összefoglalás e kettôsség szempontjából nem egyértelmú, de valamelyest az utóbbi szóhasználat felé torzít. A tagolásban tematikus felosztást próbáltam követni, de a kutatási gyakorlat erre nincs tekintettel, így ebben a vonatkozásban (sem) lehettem következetes.

Az alábbi összefoglalásból ki fog túnni, hogy a hazai kutatások elválaszthatatlanok a nemzetközi együttmúködésektôl. Ez két szinten is igaz. Elôször, a kutatók a külföldi témájuk múvelését gyakorta folytatták itthon, másodszor, számos kutatásban külföldi kutatók is részt vettek, és e kutatások váltakozva folytak hazai és külföldi laboratóriumokban.

A magyar pszichológia sajátsága, hogy a kognitív kutatásokban az idegtudományok központi helyet foglalnak el. Az okokat egy korábbi tanulmányban részletesen bemutattam (Czigler, 2019). Röviden, a kísérleti pszichológia a háború után a pavlovi irányzat hátterében indított el olyan kutatásokat, melyek idegrendszeri múködésekre (is) alapoztak, és összekapcsolódtak azzal az igénnyel, hogy neobehaviorista konstrukciók idegrendszeri alapjait kutassák. Hátteret teremtett ehhez az agyi elektromos jelenségek elemzésére alkalmas magyar fejlesztésú múszerpark. Az agyi elektromos múködések elemzése mint módszer azóta is a kognitív kutatások centrumában maradt. Ami a kutatások mennyiségét érinti, az utolsó 30 évben óvatos becslés szerint (a fejlôdési vonatkozások nélkül) a nemzetközi folyóiratokban megjelent publikációk száma több mint 350.

\footnotetext{
1 Az ELTE Összehasonlító Élettani Intézetében jelentôs kutatási irány volt a zsigeri érzékelés hatásának elemzése, kutatások folytak a szívsebesség változásának alkalmazásával, de ezek a kutatások nem kapcsolódtak kognitív irányokhoz. Az MTA Pszichológiai Kutatóintézetében egyetlen vizsgálat alkalmazott egyidejú vegetatív és agyi elektromos méréseket. Újabban az ELTE Pszichológiai Intézetében inkább affektív pszichológiai irányú kutatások folynak az elektrodermális aktivitás mérésének bevonásával. A szemmozgások elemzésével végzett és pupillometriás vizsgálatok kívül esnek az összefoglalás témakörén. Az összefoglaló nem tér ki a neuropszichológia (és ezen belül a léziós vizsgálatok) megismerési folyamatokkal kapcsolatos kutatásaira. E terület külön összefoglaló tanulmány tárgya lehet. Magyarországon jelentôs terület az alváskutatás, mely korrelatív módon, a megismerés eredményeinek kapcsán érintkezik a kognitív idegtudománnyal, de mégsem tartozik szorosan ide. A neurofiziológia és a kognitív idegtudomány elhatárolása szinte lehetetlen. A fốleg állatkísérleteken alapuló, illetve komputációs idegtudományi, tematikusan szenzoros és emlékezeti folyamatokkal kapcsolatos kutatásokra azonban az összefoglaló nem tér ki.
} 
Biztos vagyok benne, hogy az összefoglalást egyes kollégáim kiegyensúlyozatlannak fogják tekinteni (joggal). Tőlük elnézést kérek. Külön elnézést kérek név szerint nem szereplő kollégáimtól, akik mint junior kutatók a munka nagy részét végezték, és szenior kollégáimtól, akik a publikációk jelentôs részében átadták az elsố szerzô helyét.

A tematikus feldolgozásba nem illik bele, de a terület jelentôs teljesítménye a 2003-ban megjelent Kognitív idegtudomány kötet Pléh Csaba, Kovács Gyula és Gulyás Balázs szerkesztésében, 44 szerzô közremúködésével.

\section{PERCEPCIÓ}

Képek perceptuális kategorizációját az eseményhez kötött potenciálok (EKP) módszerével az (akkori) Szent-Györgyi Orvostudományi Egyetem Élettani Intézetében vizsgálták, részeként a Benedek György vezetésével végzett számos látással foglalkozó kutatásnak. Megállapították, hogy a jelentés szerinti kategorizáció már igen korán, abban az idôsávban is megjelenik, amikor az észlelési alapjelenségekre jellemzó agyi elektromos múködések is azonosíthatók (Antal, Kéri, Kovács, Janka és Benedek, 2000). Némi kitérô után a pszichológiai relevanciájú kutatások a Budapesti Múszaki és Gazdaságtudományi Egyetem (BME) Kognitív Tudományi Intézetében folytatódtak, az arcészlelésre koncentrálva, Kovács Gyula vezetésével. Az alapvetô módszertan az arcfeldolgozásra speciálisan érzékeny EKP-komponens, az N170 adaptációs változásainak vizsgálata volt (összekapcsolva pszichofizikai elemzésekkel), mely kutatások az arcészlelésben a kategoriális reprezentáció sajátságait elemezték. E kutatásokba bekapcsolódott az akkor a Pázmány Péter Katolikus Egyetem Információs Technológiai Karán dolgozó Vidnyánszky Zoltán. Természetesen e kutatások is több munkatárs bevonásával, és nemzetközi részvétellel folytak. Néhány reprezentatív publikáció: Kovács és munkatársai (2006); Zimmer (2015). A kutatásoknak ez az iránya jelenleg Zimmer Márta vezetésével folyik.

Markó és munkatársai (2009) téri élményt elődidézô random pont sztereogramoknál a kontraszt hatását vizsgálták gyors ingeradás mellett regisztrálható kiváltott potenciálokkal. Eredményeik szerint a kontraszt nem befolyásolta a sztereóhatást, ami arra utal, hogy a jelenség a nagy kontrasztérzékenységú magnocelluláris rendszer múködéséhez kötốdik.

A kognitív pszichológiában erôsödik az az irányzat, mely újra felfedezte az észlelés és mozgás elválaszthatatlan kapcsolatát. E témakörben egy újabb kutatássorozatban Horváth János és munkatársai annak a jelenségnek az okát vizsgálják, hogy a saját mozgásunkkal okozott hangok gyengébb (kisebb amplitúdójú) agykérgi elektromos válaszokat váltanak ki, mint a külsô forrásból származók (pl. Neszmélyi és Horváth, 2017).

\section{KITÉRŌ}

Talán nem elfogultságom mondatja, hogy a hazai kognitív idegtudományban vezetô szerepe van az MTA Pszichológiai Kutatóintézetének, illetve utódjainak, a Természettudományi Kutatóközpont Kognitív Idegtudományi Intézetének és Agyi Képalkotási Centrumának. Jelen összefoglaló az utóbbi harminc évvel foglalkozik. A határt cél- 
szerú némileg elmosódottan (+/-3-4 év) kezelni. Az agyi elektromos jelenségekkel kapcsolatos kutatások egyik nagy jelentôségú, Marton Magda nevéhez fưzôdô irányzatának utolsó nemzetközi folyóirat-közleményei 1988-ban jelentek meg (összefoglalásként l. Czigler, 2017), a Karmos György vezette kutatócsoport kognitív idegtudományhoz kapcsolódó elsô közleményei pedig 1987-ben (Csépe, Karmos és Molnár, 1987).

\section{ELTÉRÉS AZ ESEMÉNYEK SOROZATÁNAK SZABÁLYOSSÁGAITÓL}

Az utóbbi 30 év magyarországi kognitív idegtudományának egyik központi szereplóje kétségtelenül a finn Risto Näätänen. Az akkoriban speciális finn-magyar kapcsolatok nyomán kialakult személyes találkozások két laboratóriumban is elindítottak az ó felfedezéséhez kapcsolódó kutatásokat. A felfedezés, a „mismatch negativity” (Csépe Valéria magyarításával az „eltérési negativitás; EN”) olyan EKP-összetevő, mely akkor jön létre, ha a hangingerek sorozatában a gyakori (standard) ingerekhez képest eltérô (deviáns) inger hangzik el. Az EN érdekességét az adja, hogy nem szükséges hozzá a figyelem jelenléte, azaz kiváltja egy figyelmet igénylô feladat, vagy más, figyelmet igénylő esemény hátterében szóló deviáns hangok is. E kutatásokat akár a percepció, akár az emlékezet keretében is tárgyalhatnánk, külön fejezetbe a kutatások magyarországi népszerûsége miatt került. Az elsố olyan kísérletek, melyek e jelenséget állatkísérletekben vizsgálták (pl. Csépe és mtsai, 1987), az MTA Pszichológiai Kutatóintézet Karmos György által vezetett laboratóriumában folytak. E laboratórium munkatársainak érdeklôdése a késôbbiekben megváltozott, de az alapmódszer, az EN elemzése két kutatócsoportban mindmáig megmaradt. A nyelvhez kötött ingerekkel kapcsolatos kutatás kezdeti témája az EN eltérô érzékenysége volt a fonémák nyelvi rendszerének eltérése függvényében (Winkler és mtsai, 1999), és máig is kutatott témaként a nyelvekre jellemzố hangsúly automatikus észlelése, valamint ennek fejlôdése Csépe Valéria és Honbolygó Ferenc vezetésével (pl. Honbolygó, Kóbor, German és Csépe, 2020a). A kutatások egy másik iránya Winkler István vezetésével az EN mögött álló emlékezeti rendszer sajátságait és funkcióját vizsgálta, kimutatva, hogy e rendszer képes szabályosságok különbözô szintjeit detektálni, a rendszer plasztikus, befolyásolják hosszabb tartamú emlékezeti reprezentációk. Szerepe van egyszerre hallható hangforrások elkülönített feldolgozásában, így a hangok valósághú észlelésében. A kutatások eredményeként kiderült, hogy az EN egy olyan rendszer mutatója, mely az észlelés prediktív kódolásához kapcsolódik, azaz regisztrálja a környezeti szabályosságokat, és olyan események esetén, melyek megsértik e szabályosságokat, módosítja a várakozásokat (összefoglalásként 1. Winkler és Czigler, 2021). E témakörben a Web of Science alapján 148 publikáció jelent meg (2020. 11. 28.). Az EN kutatásai kiterjedtek újszülöttkori vizsgálatokra is (pl. Háden és mtsai, 2015), az egyéb fejôdési vizsgálatokat l. az errôl szóló elemzésben. Meg kell jegyezni, hogy az EN-kutatások többsége nemzetközi együttmúködésben zajlott. Az MTA Pszichológiai Kutatóintézet egy további kutatócsoportja az idôskori változásoknál elsôk között mutatott ki EN-változásokat (Czigler, Csibra és Csontos, 1992).

Az EN-kutatások sokáig kizárólag a hallás területén folytak, annak a meggyôzoódésnek alapján, hogy a vizuális modalitásban nincs ilyen, és nincs is szükség hasonló 
mechanizmusra. Történt ez annak ellenére, hogy például Czigler és Csibra (1992) a szabályostól eltérô, feladathoz nem kapcsolódó ingerekre a vizuális területek felett jellegzetes EKP-összetevốt regisztráltak. Amikor több, és célzottan a vizuális EN (vEN) azonosítására tervezett kísérlet is kimutatta ezt a hullámot, a vizuális eltérési negativitás (vEN) a kutatócsoport fő kutatási területévé vált. Eredményeik szerint (összefoglalásként l. Winkler és Czigler, 2021) a vizuális rendszer is automatikusan kialakítja a szabályosságok reprezentációját, és reagál az ilyen reprezentációktól való eltérésre. A vEN értelmezésében is helyet kapott a prediktív kódolás elmélete (Stefanics, Astikainen és Czigler, 2015), de felszínre kerültek ennek az értelmezésnek a korlátai is (Kojouharova, File, Sulykos és Czigler, 2019). A Web of Science (2020. 11. 28.) alapján e területen az intézetben 71 publikáció íródott.

Mind az EN és a vEN hazai kutatásai kiterjedtek speciális részt vevô csoportokra, így koraszülöttekre (Ragó, Honbolygó, Róna, Beke és Csépe, 2014) és skizofrén betegekre (Csukly, Stefanics, Komlósi, Czigler és Czobor, 2013), a Semmelweis Orvostudományi Egyetem Szülészeti és Nógyógyászati Klinikájával, illetve Pszichiátriai Klinikájával kooperációban. Az idôskori változásokkal kapcsolatos vizsgálatokkal külön fejezet foglalkozik.

\section{FIGYELEM}

A figyelmi múködések idegtudományos vizsgálatainak nagyobb része idôskori kutatásokhoz kapcsolódott, de ebben a részben az alapkutatásokkal foglalkozom (ami általában egyetemisták vizsgálatát jelenti). A feladat szempontjából releváns (figyelt) ingersajátságok szekvenciális, illetve párhuzamos szelekciójának elemzése a vizsgált periódus elsố felére esett (pl. Czigler és Géczy, 1996). A tárgyakhoz kötött figyelem vizsgálata két laboratóriumban is kutatási téma volt: EKP-módszerrel az MTA Pszichológiai Kutatóintézetében folytak kutatások (Czigler és Balázs, 1998), újabban pedig az EEG alfa sávba tartozó oszcillációjának vizsgálatával a Természettudományi Kutatóközpont Agyi Képalkotási Központjában mutatták ki, hogy képekre, illetve szavakra figyelve az illetô ingerekre specifikus területeken változott az oszcilláció mértéke (Knakker, Weiss és Vidnyánszky, 2015). A Pázmány Péter Katolikus Egyetem Információs Technológiai Karán a gyakorlás hatását vizsgálták eseményhez kötött potenciál módszerrel figyelt sajátságok (mozgásirány) detekciójára, kimutatva, hogy a vizuális elemek koherens irányú mozgására az érzékenység a specifikus vizuális területeken is nô, de a gyakorlás a döntési folyamatokat is befolyásolja (Gál és mtsai, 2010).

A hallás területén a zavaró események hatásának vizsgálatában indult kutatássorozat. Az EKP-eljárás lényege itt az, hogy egy feladathoz kötött sajátság (pl. hangok hosszúsága) diszkriminációját mennyire befolyásolja a teljesítmény és az EKP-változások szintjén, ha a hang egyéb sajátsága (pl. magassága) időnként megváltozik. A figyelmi rendszer felhasznál ilyenkor az események megjelenésével kapcsolatos idôi és szekvenciális információkat, egy újabb vizsgálatban pedig Volosin és Horváth (2020) kimutatták, hogy az ilyen zavaró hatásokra a feldolgozó rendszer ellenállónak mutatkozik, a zavarás intenzitásával képes fokozni a figyelmi múködések hatékonyságát. 
A szelektív figyelem klasszikus „koktélparti” vizsgálatának egy modern változatában Tóth és munkatársai (2020) funkcionális konnektivitási módszerrel (agyi területek közötti összeköttetés egyes EEG-frekvencia-összetevők szinkronitása alapján) úgy találták, hogy a feladat szempontjából zavaró beszéd figyelmi szúrése a feldolgozásnak nem egy korábbi szakaszában történik, azaz az eredmények a késôi szúrés múködésmódját valószínúsítik. Hasonló elrendezésú EKP-vizsgálatban Szalardy és munkatársai (2020) eredményei szerint a nyelvi előrejelzés hozzájárul a beszédforrások szétválasztásához, ami újólag a feldolgozás egy késóbbi szakaszának szerepére utal.

\section{TANULÁS, EMLÉKEZÉS}

A Németh Dezsô és munkatársai által extenzíven vizsgált szekvenciális tanulás sajátságainak elemzésére végzett EKP-vizsgálatokban Kóbor és munkatársai (2019) kimutatták, hogy azok a változások, melyeket általában figyelmi folyamatokhoz kapcsolunk, megmutatkoznak implicit, azaz nem tudatosuló tanulási folyamatokban is.

Arcok részletes emlékezeti megtartását vizsgálva Bankó és Vidnyánszky (2010) az egyes EKP-összetevôkben a megtartási idô eltérô hatását tapasztalták, ami a megtartási idô függvényében eltérô emlékezeti visszahívási folyamatokra utal.

Egy eddig még nem említett módszert, az egyenáramú (stimuláló) ingerlést alkalmazva Marián, Szólloosi és Racsmány (2018) a központi végrehajtó folyamatok szerepét elemezték hosszú tartamú (7 map) emlékezeti megtartásban a (magyar résztvevook számára) értelmetlen és értelmes szavak páros asszociációs tanulásában. Az eredmények szerint az ingerlés akkor csökkentette a teljesítményt, ha azt közvetlenül az elôtt alkalmazták, amikor a résztvevók újra találkoztak az ingeranyaggal. Interpretációjuk szerint a frontális kontroll elôzetes aktivitása csökkenti a hosszú tartamú megjegyzés folyamatait.

Jelentôs összefoglalót készített Kéri Szabolcs (Kéri, 2003) a kategoriális tanulás idegrendszeri mechanizmusairól.

\section{AZ EEG-FREKVENCIA ELEMZÉSE, KOMPLEXITÁS, HÁLÓZATOK}

Az EEG komplexitáselemzésének alkalmazását az MTA Pszichológiai Kutatóintézetében a Molnár Márk által vezetett csoport indította el. E kutatások módszertana az EEG-jel összetettségét különbözô számítástechnikai módszerekkel vizsgálja, mely módszerek alkalmasak különbözô, az átlagos népességtôl eltérô csoportok kognitív múködésének jellemzésére. A kutatásoknak ez a vonulata elvezetett az agyi területek szinkron múködésein alapuló hálózati elemzésekhez.

Az EEG komplexitáselemzésére példa Molnár (1999) vizsgálata, melyben ritka célingerekre kellett válaszolni könnyú és nehéz diszkriminációs feltételben. Az eredmények szerint a célingerek által kiváltott késôi pozitív összetevô alatt a komplexitás csökkent, ami arra utalhat, hogy a releváns inger utóhatásaként gátló folyamatok múködnek. Az EEG-frekvencia elemzésének és komplexitásának egyidejû vizsgálata 
lehetôvé tette várakozási helyzetben a kontroll és anticipációs múködésének elemzését (Molnár és mtsai, 2008). Képek munkaemlékezeti megtartása esetén az EEG-frekvencia sávokon alapuló hálózati elemzése a lassabb (delta és téta) sávban mutatott ki hálózati kapcsolatokat elülsô és hátsó területek között (Tóth és mtsai, 2012). A csoport számos kutatása idôskori változásokhoz kapcsolódó és speciális humán múködésekkel foglalkozik, ezekrôl késôbb lesz szó.

\section{SPECIFIKUS HUMÁN KOGNITÍV MÜKÖDÉSEK}

Az olvasás és számolás idegtudományi vizsgálata az MTA Pszichológiai Kutatóintézetének, majd a TTK Agyi Képalkotási Központjának fontos, fooként fejlődéslélektani orientációjú témája. A területról Csépe Valéria Az olvasó agy címmel jelentetett meg monográfiát (Csépe, 2006). A beszédfeldolgozásban a hangsúly hatását vizsgálták Honbolygó és munkatársai (2020b). Eseményhez kötött fMRI-vizsgálatban kimutatták a superior temporális gyrus szerepét a hangsúly prediktív feldolgozásában. A szemmozgásokat kísérô agyi elektromos változásokat elemezték Weiss, Knakker és Vidnyánszky (2016). Az EKP-eredményekben megmutatkozott a gyakorlottság és a szavak közötti távolság jelentôs hatása.

Talán furcsa, hogy a humánspecifikus múködések keretében tárgyalom, de idekívánkozik az ember-kutya kapcsolatok vizsgálatának szempontjából az a kutatás, mely fMRI-adaptációs paradigmában vizsgálta kutyáknál a természetes emberi beszéd feldolgozását (Boros és mtsai, 2020). Az eredmények szerint az elsôdleges akusztikus kéreg nem, viszont a másodlagos akusztikus kéreg érzékenységet mutatott szupraszegmentális információkra (a beszélô azonossága).

A numerikus megismerés elektrofiziológiai vizsgálatának hazai kutatásaiban Szúcs és Csépe (2005) összeadásnál a valós eredmények és a bemutatott eredmények valószínûségének eltérését és az eltérés nagyságát vizsgálva találtak különbözô hatásokat. Az idôsödéshez kapcsolódó kutatások ezúttal is külön fejezetbe kerülnek.

\section{SPECIÁLIS CSOPORTOK, KÜLÖNLEGES KÖRÜLMÉNYEK}

E heterogén fejezetben olyan csoportok vizsgálatáról lesz szó, melyek egyéb fejezetekben nem szerepeltek. Ebbe a körbe tartozik, hogy tompalátás (amblyopia) esetében arcok bemutatásakor a látórendszer magasabb szintjein is eltér a feldolgozás (pl. Bankó, Körtvélyes, Németh, Weiss és Vidnyánszky, 2013). Skizofrén betegeknél a téta hullám változásában mutatkozott különbség az arcok feldolgozásában (Csukly, Stefanics, Komlósi, Czigler és Czobor, 2014).

A figyelmi múködések szempontjából speciálisan teljesítô csoportban, élsportoló céllövốknél a vizuális figyelemre jellemzó EKP-komponensek nagyobb amplitúdóval jelentkeztek, mint a kontrollcsoportban, ami hatékonyabb figyelmi múködésekre utal. Ugyanakkor a releváns és irreleváns események elkülönítésében nem mutatkoztak stratégiai eltérések a két csoport között (Czigler, Balázs és Lénárt, 1999). 
A különleges csoportok közé tartoznak az ûrhajósok is. A Nemzetközi Ûrállomáson Balázs László és munkatársai által végzett vizsgálatokból eddig egy nemzetközi összefogásban megjelent közlemény jelent meg (Cebolla és mtsai, 2016), melyben súlytalanságban vizsgáltak vizuális figyelemhez kötôdô alfaaktivitás-változásokat.

Különleges helyzet a hipoxia kognitív múködésekben megnyilvánuló hatása. Balázs László és kollégáinak eredményei szerint (Altbäcker, Takács, Barkaszi, Kormos és Czigler, 2019) károsodás föleg az új, váratlan ingerekre specifikus EKP-összetevôkben észlelhetô. Sarkkutatóknál viszont az extrém körülmények között az agyi elektromos múködésekben nem mutattak számottevô változásokat (Barkaszi, Takács, Czigler és Balázs, 2016). Hasonló módon, mentális fáradtság esetén is stabilnak mutatkoztak a kognitív múködésekre specifikus agyi elektromos mutatók (Takács, Barkaszi, Albäcker, Czigler és Balázs, 2019).

\section{KOGNITÍV IDEGTUDOMÁNY ÉS ÖREGEDÉS}

E témakör akár külön tanulmányt érdemelne, mivel az idôskori kognitív változások hazai idegtudományos vizsgálata számos területet és módszert érint, a publikációk mennyisége pedig csak az MTA Pszichológiai Kutatóintézetében és utódszervezeteiben több mint 30. Az idôsödéssel jelentkezô kognitív változások megismerésének fontosságát nem kell hangsúlyozni, de mint a terület kutatója talán megengedhetem magamnak azt a cinikus megjegyzést, hogy öregek csoportjai könnyebben vizsgálhatók, mint más, az egyetemi hallgatóktól eltérô csoportok. A kutatásokat néhány speciális terület bemutatásával illusztrálom.

A feladathoz nem kapcsolódó események feldolgozásának vizsgálatára lehetôséget teremt az EN az akusztikus és vizuális modalitásban. Az időskori változásokban általános kognitív lassulás volt kimutatható a hangsorozatokban eltereló ingereket vizsgálva úgy az EN-, mint az azt követô, az automatikus orientációt jelzô összetevôkben (Horváth, Czigler, Birkás, Winkler és Gervai, 2009). Az automatikus folyamatok időskori lassulása hozzájárulhat az egymást gyorsan követô események károsult feldolgozásához (Volosin és Horváth, 2017a). A vizuális EN vizsgálataiból kiemelem azt a kutatást, mely az idôskorban az elhúzódó (lassabban csillapuló) folyamatok elônyét mutatta ki. Az ingerek hatásának hosszabb lecsengése idôs személyeknél avval járt, hogy két egymás utáni szótöredék között ebben a csoportban hosszabb idô után is létrejön a jelentés szerinti integráció, ami már az automatikus feldolgozás szintjén is megmutatkozik (Gaál, Bodnár és Czigler, 2017). A lassulás mellett általános okként tartják számon egyes gátlási folyamatok hatékonyságának idôskori csökkenését. A hangok világában e zavaró hatást több kutatás elemezte. Példaként, kismértékben emelkedett hatást találtak idôseknél Volosin és Horváth (2017b). A zavaró ingerek hatásában a vizuális modalitásban nem mindig mutatkoznak teljesítménykülönbségek idôs és fiatal csoportok között. Az EKP-elemzések segítségével viszont kimutatható, hogy idôs személyek más mechanizmusokat alkalmaznak a zavaró ingerek hatásának kiküszöbölésére, mint a fiatalok (Kojouhaova, Gaál, Nagy és Czigler, 2020). Máskor az egyes próbákhoz nem kötôdô, az eseménysorozatok általános sajátságaira mutatkozik kisebb érzékenység 
(Czigler és Balázs, 2005). Az információfeldolgozásban mutatkozó stratégiai különbségeket mutatják Kardos, Kóbor és Molnár (2020) eredményei is.

Komplexebb paradigmákban, így feladatváltásos helyzetekben megmutatkozik idôs személyeknél a gátlási múködések hiányából fakadó teljesítménycsökkenés. Ennek megfelelốen a teljesítménycsökkenés mellett lényegesen csökkennek az információfeldolgozás késóbbi szakaszaira jellemzô eseményhez kötött potenciál komponensek amplitúdói (Gaál és Czigler, 2015), de ezek az életkori eltérések masszív tréninggel megszüntethetôk (Gaál és Czigler, 2018).

Az EKP-módszer alkalmasnak bizonyult kockázatvállalási eltérések vizsgálatára életkori csoportok között. Kardos és munkatársai (2016) sorozatosan egyre kockázatosabb, de egyre nagyobb jutalommal járó helyzetben a döntést követố visszajelzés hatását vizsgálták. A fiataloknál a döntéshez kapcsolódó eseményhez kötött potenciál-összetevố nagysága a döntési szekvenciával változott, időseknél viszont nem volt ilyen összefüggés.

Az idôskori változások egy további iránya azokat a kognitív múködéseket megalapozó idegrendszeri történéseket vizsgálja, melyek az életkor előrehaladtával megmutatkozó változásokhoz vezetnek. Ez megmutatkozhat az EEG egyes frekvenciasávjainak komplexitásváltozásában, egyes frekvenciasávok szinkronizációja alapján az idegrendszeri területek kapcsolatrendszerének átalakulásában (pl. Gaál és mtsai, 2010). A munkamemória életkori teljesítménycsökkenését vizsgálva Tóth és munkatársai (2014) megállapították, hogy idôseknél inkább a frontális területeken belüli hálózatok változnak, mint a frontális és hátsó területek közötti kapcsolatok.

\section{KÖVETKEZTETÉSEK ÉS PREDIKCIÓK}

A kognitív pszichológia és az idegtudomány összefonódása a hazai hagyományokat folytatva az utóbb harminc évben is az egyik vezetô terület maradt. Tematikus szempontból lényegesek voltak azok a területek, melyek vizsgálatát a vezetô kutatók külföldi munkájuk után itthon is kezdeményezték. Példaként említhetjük az automatikus változásdetekció vizsgálatát, vagy az EEG-komplexitás elemzését. Míg kezdetben a legtöbb vizsgálat a pszichológiai jelenségek teoretikus megközelítéséhez kapcsolódott, egyre inkább nôtt azoknak a kutatásoknak a száma, melyek az eredményeket speciális csoportokban, leggyakrabban idôs személyeknél vizsgálták (mint többször említettem, jelen összefoglaló nem tér ki a fejlôdéspszichológiai kutatásokra, ahol jelen szerzô véleménye szerint hasonló tendencia mutatkozik).

A kutatások zöme néhány múhelyhez, és az e múhelyeket befogadó intézményekhez kötôdik, ami azt mutatja, hogy az eredményes kutatásokat nagyban segíti, ha az infrastruktúra elér egy kritikus tömeget. Észre kell venni, hogy ezekben az intézményekben jelenleg a vezetô kutatók szempontjából egyrészt generációváltás, másrészt tematikus váltás kezdôdött, illetve várható, olyan integratív témák megjelenésével, mint a társas múködések bevonása az idegtudományos vizsgálatokba, vagy kiterjedtebb, longitudinális vizsgálatok speciális populációk esetén. Az elvi lehetôség nyitva áll az együttmúködésre a humán kognitív múködéseket és az alapvetô idegrendszeri folyamatok elemzését végzố csoportok között a koordinált kutatásokra. Csak remélni 
lehet, hogy erre egyre gyakrabban kerül sor. Mint a terület (még) aktív múvelőjétôl nem várható tôlem elfogultság nélküli állásfoglalás a hazai kutatások általános színvonaláról. Véleményem szerint e területen a kutatások színvonala, beleértve a publikációk mennyiségét és minôségét, megfelel a nemzetközi élvonalnak.

Látható volt, hogy a kognitív idegtudományi kutatásokban a fó módszertan az eseményhez kötött agyi aktivitás vizsgálata (EKP-módszerek) volt, ami kiegészült az egyes frekvenciatartományok és ezen keresztül az idegrendszeri hálózatok elemzésével. A humán megismerési folyamatok kutatásában a képalkotási módszerek magyarországi alkalmazása egyelốre viszonylag csekély mértékú, csak remélni lehet, hogy ez a jövőben nőni fog. Idekívánkozik a „cinikus megjegyzés”: úgy tûnik, a kutatások presztízsét jelentő „nagy impakt faktorú” folyóiratokban a kutatási módszerek anyagi igénye nem jelentéktelen elfogadási tényezô, így ezekben az EKP-módszer némileg hátrányos helyzetbe kerül.

Végezetül: „Mi hiányzik?” A kognitív idegtudományos kutatások elég messze kerültek a hazai alkalmazott pszichológusoktól; elég csak a Magyar Pszichológiai Társaság nagygyúléseinek programfüzeteire gondolni, melyekból ez a téma szinte teljesen hiányzik. A közeledés útjait remélhetôleg megtalálja a következô generáció.

\section{KÖSZÖNETNYILVÁNÍTÁS}

A kézirat elkészítésében megköszönöm Gaál Zsófia Anna segítségét, és az NKFIH (119587) támogatását.

\section{IRODALOM}

Altbäcker, A., Takács, E., Barkaszi, I., Kormos, T., \& Czigler, I. (2019). Differential impact of acute hypoxia on event related potentials: impaired task-irrelevant, but preserved taskrelevant processing and response inhibition. Physiology and Behavior, 206, 28-36.

Antal, A., Kéri, S., Kovács, G., Janka, Z., \& Benedek, G. (2000). Early and late components of visual categorization: An event-related potential study. Cognitive Brain Research, 9(1), $117-119$.

Bankó, E., Körtvélyes, J., Németh, J., Weiss, B., \& Vidnyánszky, Z. (2013). Amblyopic deficits in the timing and strength of visual cortical responses to faces. Cortex, 49(4), 1013-1024.

Bankó, E. M., \& Vidnyánszky, Z. (2010). Retention Interval affects visual short-term memory encoding. Journal of Neurophysiology, 103(3), 1425-1430.

Barkaszi, I., Takács, E., Czigler, I., \& Balázs, L. (2016). Extreme environment effects on cognitive functions: A longitudinal study in high altitude in Antarctica. Frontiers in Human Neuroscience, 10, Article Number: 331.

Boros, M., Gábor, A., Szabó, D., Bozsik, A., Gácsi, M., Szalay F., et al. (2020). Repetition enhancement to voice identities in the dog brain. Scientific Reports, 10, Article Number: 3989.

Cebolla, A. M., Petieau, M., Dan, B., Balazs, L., McIntyre, J., \& Cheron, G . (2016). Cerebellar contribution to visuo-attentional alpha rhythm: insights from weightlessness. Scientific Reports, 6, Article Number: 37824. 
Czigler, I. (2017). Marton Magda munkái a kísérleti pszichológiában. Magyar Pszichológiai Szemle, 72(3), 427-439.

Czigler, I. (2019). Agy és elme: szerencsés találkozások. In Bollobás, E. (Ed.), Elméletek vonzásában: A „határtalan tudomány” kezdetei a hatvanas-hetvenes évek humán és társadalomtudományi kutatásaiban (pp. 156-182). Budapest: Gondolat.

Czigler, I., \& Balázs, L. (1998). Object-related attention: An event-related potential study. Brain and Cognition, 38(2), 113-124.

Czigler, I., Balázs, L., \& Lénárt, A. (1999). Attention to features of separate objects: an ERP study of target-shooters and control participants. International Journal of Psychophysiology, 31(1), $77-87$.

Czigler, I., \& Balázs, L. (2005). Age-related effects of novel visual stimuli in a letter-matching task: an event-related potential study. Biological Psychology, 69(2), 229-242.

Czigler, I., Csibra, G., \& Csontos, A. (1992). Age and inter-stimulus interval effects on event-related potentials to frequent and infrequent auditory-stimuli. Biological Psychology, 33(2-3), 195-206.

Czigler, I., \& Csibra, G. (1992). Event-related potentials and the identification of deviant visual-stimuli. Psychophysiology, 29(4), 471-485.

Czigler, I., \& Géczy, I. (1996). Event-related potential correlates of color selection and lexical decision: hierarchical processing or late selection? International Journal of Psychophysiology, $22,67-84$.

Csépe, V. (2006). Az olvasó agy. Budapest: Akadémiai Kiadó.

Csépe, V., Karmos, G., \& Molnár, M. (1987). Evoked-potential correlates of stimulus deviance during wakefulness and sleep in cat - animal-model of mismatch negativity. Electroencephalography and Clinical Neurophysiology, 66, 571-578.

Csukly, G., Stefanics, G., Komlósi, S., Czigler, I., \& Czobor, P. (2013). Emotion-related visual mismatch responses in schizophrenoia: Impairments and correlations with emotion recognition. Plos One, 8, Article Number: e75444.

Csukly, G., Stefanics, G., Komlósi, S., Czigler, I., \& Czobor, P. (2014). Event-related theta synchronization predicts deficit in facial affect recognition in schizophrenia. Journal of Abnormal Psychology, 123(1), 178-189.

Gál, V., Kóbor, I., Bankó, E. M., Kozák, L. R., Serences, J. T., \& Vidnyánszky, Z. (2010). Electrophysiological correlates of learning-induced modulation of visual motion processing in humans. Frontiers in Human Neuroscience, 3, Article Number: 69.

Gaál., Z. A., Boha R., Stam, C. J., \& Molnár, M. (2010). Age-dependent features of EEG-reactivity-Spectral, complexity, and network characteristics. Neuroscience Letters, 479(1), 79-84.

Gaál, Zs. A., \& Czigler, I. (2015). Age-related processing strategies and go-nogo effects in task-switching: an ERP study. Frontiers in Human Neuroscience, 9, Article Number: 177.

Gaál, Zs. A., Bodnár, F., \& Czigler, I. (2017). When elderly outperform young adults - Integration in vision revealed by the visual mismatch negativity. Frontiers in Aging Neuroscience, 9, Article Number: 15.

Gaál, Zs. A., \& Czigler, I. (2018). Task-switching training and transfer. Journal of Psychophysiology, 32(3), 106-130.

Háden, G., Németh, R., Török, M., \& Winkler, I. (2015). Predictive processing of pitch trends in newborn infants. Brain Research, 1626, 14-20.

Honbolygó, F., Kóbor, A., German, B., \& Csépe, V. (2020a). Word stress representations are language-specific: Evidence from event-related brain potentials. Psychophysiology, 57, Article Number: e13541. 
Honbolygó, F., Kóbor, A., Hermann, P., Kettinger, Á. O., Vidnyánszky, Z., Kovács G., \& Csépe, V. (2020b). Expectations about word stress modulate neural activity in speech-sensitive cortical areas. Neuropsychologia, 143, Article Number: 107467.

Horváth, J., Czigler, I., Birkás, E., Winkler, I., \& Gervai, J. (2009). Age-related differences in distraction and reorientation in an auditory task. Neurobiology of Aging, 30(7), 1157-1172.

Kardos, Z., Kóbor, A., Takács, A., Tóth B., Boha, R., File, B., \& Molnár, M. (2016). Age-related characteristics of risky decision-making and progressive expectation formation. Behavioural Brain Research, 312, 405-414.

Kardos, Z., Kóbor, A., \& Molnár, M. (2020). Accurate response selection and Inhibition in healthy aging: An Event-related potential study. Psychology and Aging, 35(5), 720-728.

Kéri, S. (2003). The cognitive neuroscience of category learning. Brain Science Reviews, 43(1), 85-109.

Knakker, B., Weiss, B., \& Vidnyánszky, Z. (2015). Object-based attentional selection modulates anticipatory alpha oscillations. Frontiers in Human Neuroscience, 8, Article Number: 1048.

Kóbor, A., Horváth, K., Kardos, Z., Takács, A., Janacsek, K., Csépe, V., \& Németh, D. (2019). Tracking the implicit acquisition of nonadjacent transitional probabilities by ERPs. Memory and Cognition, 47(8), 1546-1566.

Kojouharova, P., Gaál, Z., Nagy, B., \& Czigler, I. (2020). Age effects on distraction in a visual task requiring fast reactions: An event-related potential study. Frontiers in Aging Neuroscience, 12, Article number: 596047.

Kojouharova, P., File, D., Sulykos, I., \& Czigler, I. (2019). Visual mismatch negativity and stimulus-specific adaptation: the role of stimulus complexity. Experimental Brain Research, 237(5), $1179-1194$.

Kovács, G., Zimmer, M., Bankó E., Harza, I., Antal, A., \& Vidnyánszky, Z. (2006). Electrophysiological correlates of visual adaptation to faces and body parts in humans. Cerebral Cortex, 16(5), 742-753.

Marián, M., Szőllôsi, Á., \& Racsmány, M. (2018). Anodal transcranial direct current stimulation of the right dorsolateral prefrontal cortex impairs long-term retention of reencountered memories. Cortex, 108, 80-91.

Markó, K., Kiss, H. J. M., Mikó-Baráth, E., Bártfai, O., Török, B., Kovács, I., \& Jandó, G. (2009). Contrast independence of dynamic random dot correlogram evoked VEP amplitude. Journal of Vision, 8, Article number: 9.

Molnár, M. (1999). The dimensional complexity of the P3 event-related potential: area-specific and task-dependent features. Clinical Neurophysiology, 110, 31-38.

Molnár, M., Csuhaj, R., Gaál, Z. A., Czigler, B., Ulbert, I., Boha, R., \& Kondakor, I. (2008). Spectral characteristics and linear-nonlinear synchronization changes of different EEG frequency bands during the CNV. Psychophysiology, 45(3), 412-419.

Neszmélyi, B., \& Horváth, J. (2017). Consequences matter: Self-induced tones are used as feedback to optimize tone. Psychophysiology, 54(6), 904-915.

Pléh, Cs., Kovács, Gy., \& Gulyás, B. (Eds) (2003). Kognitív idegtudomány. Budapest: Osiris.

Ragó, A., Honbolygó, F., Róna, Z., Beke, A., \& Csépe, V. (2014). Effect of maturation on suprasegmental speech processing in full- and preterm infants: A mismatch negativity study. Research in Developmental Disabilities, 35(1), 192-202.

Stefanics, G., Astikainen, P., \& Czigler, I. (2015). Visual mismatch negativity (vMMN): a prediction error signal in the visual modality. Frontiers in Human Neuroscience, 8, Article Number: 1074 .

Szalardy, O., Tóth, B., Farkas, D., Orosz, G., Honbolygó, F., \& Winkler, I. (2020). Linguistic predictability influences auditory stimulus classification within two concurrent speech streams. Psychophysiology, 57, Article Number: e13547. 
Szúcs, D., \& Csépe, V. (2005). The effect of numerical distance and stimulus probability on ERP components elicited by numerical incongruencies in mental addition. Cognitive Brain Research, 22(2), 289-300.

Takács, E., Barkaszi, I., Albäcker A., Czigler, I., \& Balázs, L. (2019). Cognitive resilience after prolonged task performance: an ERP investigation. Experimental Brain Research, 237, 377-388.

Tóth, B., Boha, R., Pósfai, M., Gaál, Z. A., Kónya, A., Stam, C. J., \& Molnár, M. (2012). EEG synchronization characteristics of functional connectivity and complex network properties of memory maintenance in the delta and theta frequency bands. International Journal of Psychophysiology, 83(3), 399-402.

Tóth, B., Kardos, Z., File, B., Boha, R., Stam, C. J., \& Molnár, M. (2014). Frontal midline theta connectivity is related to efficiency of WM maintenance and is affected by aging. Neurobiology of Learning and Memory, 114, 58-69.

Tóth, B., Honbolygó, F., Szalardy, O., Orosz, G., Farkas, D., \& Winkler, I. (2020). The effects of speech processing units on auditory stream segregation and selective attention in a multi-talker (cocktail party) situation. Cortex, 130, 387-400.

Volosin, M., \& Horváth, J. (2017a). Age-related processing delay reveals cause of apparent sensory excitability following auditory stimulation. Scientific Reports, 7, Article Number: 10143.

Volosin, M., \& Horváth, J. (2017b). Task-optimal auditory attention set restored as fast in older as in younger adults after distraction. Biological Psychology, 126, 71-81.

Volosin, M., \& Horváth, J. (2020). Task difficulty modulates voluntary attention allocation, but not distraction in an auditory distraction paradigm. Brain Research, 1727, Article Volume: 1727.

Weiss, B., Knakker, B., \& Vidnyánszky, Z. (2016). Visual processing during reading. Scientific Reports, 6, Article Number: 26902.

Winkler, I., \& Czigler, I. (2021). Látási és hallási változás-detekció. Megjelenés alatt.

Winkler, I., Kujala, T., Tiitinen, H., Sivonen, P., Alku, P., Lehtokoski, A., et al. (1999). Brain responses reveal the learning of foreign language phonemes. Psychophysiology, 36, 638-672.

Zimmer, M., Zban, A., Németh, C., \& Kovács G. (2015). Adaptation duration dissociates category-, image-, and person-specific processes on face-evoked event-related potentials. Frontiers in Psychology, 6(141), Article Number: 1945. 


\section{COGNITIVE NEUROSCIENCE IN HUNGARY: 30 YEARS}

\section{CZIGLER, ISTVÁN}

Concentrating on electrophysiological studies the author reviews Hungarian neuroscience research on the fields of perception, attention, learning and memory. As a specific topic, he reviews results on human aging.

Keywords: perception, attention, memory, language, aging, perspectives

A cikk a Creative Commons Attribution 4.0 International License (https://creativecommons. org/licenses/by/4.0/) feltételei szerint publikált Open Access közlemény, melynek szellemében a cikk bármilyen médiumban szabadon felhasználható, megosztható és újraközölhetô, feltéve, hogy az eredeti szerzô és a közlés helye, illetve a CC License linkje és az esetlegesen végrehajtott módosítások feltüntetésre kerülnek. (SID_1) 